\title{
The Formulation of Classification for Islamization in Medicine: Review on 15 Years of Publications from Kulliyyah of Medicine
}

\author{
Mohammad Arif Shahar ${ }^{1}$, Mohd Faiz Idris ${ }^{1}$, Che Anuar Che Mohamad ${ }^{2}$, Zul Azlin Razali ${ }^{3}$ \\ ${ }^{1}$ Kulliyyah of Medicine, International Islamic University Malaysia ${ }^{2}$ Kulliyyah of Pharmacy, International \\ Islamic University Malaysia ${ }^{3}$ Faculty of Medicine and Health Sciences, Universiti Sains Islam Malaysia
}

\begin{abstract}
The Kulliyyah of Medicine of IIUM has pioneered the Islamization of Medicine in Malaysia since its establishment in year 1994. Therefore, it is timely to review publications on Islamization by the kulliyyah and also to propose a classification system in the field of researches to promote an organized, comprehensive, inclusive and relevant Islamization process. The aim is to review and classify publications on Islamization performed by the members of Kulliyyah of Medicine, International Islamic University Malaysia (IIUM). All researches and publications deposited in the IIUM Repository (IREP) under the Kulliyyah of Medicine between $1^{\text {st }}$ of January 2000 and $31^{\text {st }}$ of August 2016 were reviewed. Journal articles, posters and proceedings with Islamization themes were identified. These publications were classified based on common themes to either of the following; 1) "Islamic Principles and Related Rulings in Medicine"; 2) "Medical Treatment for Muslim Patients"; 3) "Islamic Input in Medical Practices"; 4) "Ruqyah and Tibb an-Nabawi in Contemporary Medicine". A total of 1616 items (journal articles, abstracts and proceedings) were reviewed. Sixty-one $(3.8 \%)$ of them were related to Islamization. The major contributors to writings in Islamization are the Orthopaedics, Traumatology and Rehabilitation Department $(10 \%)$ followed by the Internal Medicine Department (7.9\%), from their total deposits in the IREP database. Majority (36.5\%) of work were done in "Islamic Principles and Related Rulings in Medicine", which dwells in subjects such as euthanasia, autonomy and doctor-patient relationship followed by "Islamic Input in Medical Practice" (28.6\%) which was related to topics in the medical curriculum such as Fiqh Ibadah for the sick. Twenty-three point eight percent (23.8\%) of work were in the "Medical Treatment for Muslim Patients" which focuses on Ramadan and diabetes and joint problems and Solat. Minimal work (7.9\%) was done in the "Ruqyah and Tibb an-Nabawi in Contemporary Medicine" category. Low number of publications on Islamization was deposited in the IREP database for the past 15 years. Based on the proposed classification system, majority of publications were on "Islamic Principles and Related Rulings in Medicine" and "Islamic Input in Medical Practice". More work is required on the theme of "Medical Treatment for Muslim Patients" and "Ruqyah and Tibb an-Nabawi in Contemporary Medicine".
\end{abstract}

KEYWORDS: Islamization, Islamic input in medicine, Islamic ruling, medical education, Islamic Medicine, Tibb An-Nabawi, Ruqyah, Modern Medicine

\section{INTRODUCTION}

Although current evidence based medicine stem from Islamic predecessors such as Ibn Sina and Ibn Rushd, it has been regarded as a "Western-owned" discipline. While medical technology and researches started to decline in the Muslim empire, with the fall of Abbasid Caliphate, it continues to flourish in Europe and the other part of Western world. The repercussion of this event in history is the dichotomy in medicine. On one hand, "Islamic Medicine" is regarded as medical practices and technology originated from Arabia during the time of the Prophet Muhammad (Peace be upon him) till the days of Ibn Sina and Ibn Rushd, and on the other hand, "Modern Medicine" is considered as medicine originated from the Greco- Roman civilization during the time of Hippocrates and Sir William Osler till our modern days. While in actual fact, there was ample evidences that the so-called "Islamic Medicine" was the result of translation, rereading and interpretation of Greco-Roman works (e.g Hippocrates) by the first batches of doctors

Email: arifshahar@iium.edu.my in Umayyad and Abbassid era (both Muslim and non-Muslim a-like). ${ }^{1,2}$ Like-wise, the so-called "Modern Medicine" was the result of the Western world studying the Canon of Medicine by Ibn Sina. Unfortunately, this dichotomy in medicine continues to be present in our society till today.

There are several negative implications as a result of the dichotomy in medicine which affect health. One of the examples is the anti-vaccine movement in our part of the world, who denounced "Modern Medicine" and embraces what they thought to be "Islamic Medicine". While in actual fact the principle of "prevention of the spread of contagious diseases' has been inculcated by the Prophet himself when he said "If you hear of an outbreak of plague in a land, do not enter it; but if the plague breaks out in a place while you are in it, do not leave that place" (Sahih Bukhari). This hadith clearly proposed a preventive measure which modern medicine termed as 'quarantine'. What could be more Islamic than vaccination to prevent communicable disease? As a result of the anti-vaccine movement, there is an emergence of preventable infectious diseases such as diphtheria in Malaysia. The number of cases has increased 
from 0 case in 2011 to 13 confirmed cases in 2016 and till today 5 deaths has been reported. ${ }^{3,4}$ Causing harm is clearly against the principles of Islam.

Islamization in medicine is one of the solutions to the dichotomy in medicine. Islamization in medicine is not merely an attempt to recover Muslims' selfesteem from the fall of its civilization after the Ottoman Caliphate, or to revive the Muslim glory in medicine, but more importantly, the purpose is to safeguard man's health from being jeopardized by wrong and narrow interpretations of "Islamic Medicine". Islamization of medicine is also not an apologetic stance taken by modern Muslim scholars. It is common in our society that "Islamic Medicine" is perceived exclusively as Tibb an-Nabawi and Ruqyah (anything other than "Modern Medicine"). Questions that would arise following this perception are: 1) Is there such a thing as "Non-Islamic Medicine" as opposed to "Islamic Medicine"? 2) Is Modern Medicine a "Kuffar Medicine" since it is nonIslamic? 3) Is Islamization and attempt to convert medicine into Islam? This is why the term "Islamic Medicine" with such narrow interpretation is flawed.

The ultimate aim of the Islamization process in medicine is to educate the society, be it Muslim or non-Muslim, that 'medicine is medicine' and Islamic Medicine are practices in medicine which are govern by the principles of Islam. In other words, Islamic Medicine could be defined as any medical practice or technology - be it modern or alternative governed by Islamic principles of Tawheed, Shariah and Akhlaq. Tibb an-Nabawi and Ruqyah is not exclusively Islamic Medicine, rather it is, a small part of medicine itself (Figure 1). There should be no dichotomy between Islamic Medicine and Modern medicine.

The Kulliyyah of Medicine, International Islamic University Malaysia (IIUM) is considered a pioneer in the Islamization of medicine and the process has been going on for the past 15 years. However, despite the long-term effort by the kulliyyah members, dichotomy in medicine is still at large among health practitioners and the public. Therefore, a review of work of Islamization in the kulliyyah is timely. This paper aimed at reviewing and classifying publications on Islamization done in Kulliyyah of Medicine, IIUM. The proposed classification will hopefully further facilitate the process of Islamization in medicine into a more organized effort, inclusive of all aspect of medicine and relevant to current medical practice in the society.

\section{METHODS}

Access to the IREP was made between $1^{\text {st }}$ and $31^{\text {st }}$ of August 2016. All researches and publications deposited in the IIUM Repository (IREP) under the Kulliyyah of Medicine between $1^{\text {st }}$ of January 2000 and $31^{\text {st }}$ of August 2016 were reviewed. Journal articles, posters and proceedings with Islamization themes were identified. These publications were classified based on common themes to either of the following; 1) "Islamic Principles and Related Rulings in Medicine"; 2) "Medical Treatment for Muslim Patients"; 3) "Islamic Input in Medical Practices"; 4) "Ruqyah and Tibb an-Nabawi in Contemporary Medicine" (Figure 2). Categorization by department is based on the first author. Same publication deposited by more than one department is counted as a unique item.

\section{RESULTS}

A total of 1616 items (journal articles, abstracts and proceedings) were reviewed. Sixty-one (3.8\%) of them were related to Islamization (Figure 3 ). The major contributors to writings in Islamization are the Orthopaedics, Traumatology and Rehabilitation Department $(10 \%)$ and the Internal Medicine Department $(7.9 \%)$, from their total deposits in the IREP database. Other departments contributed to less than $6.5 \%$ of their publications. The lowest work on Islamization deposited in the IREP database was from the Basic Medical Sciences Department (Figure 4). Majority $(36.5 \%)$ of work were done in "Islamic Principles and Related Rulings in Medicine", which dwells in subjects such as euthanasia, autonomy and doctor-patient relationship followed by "Islamic Input in Medical Practice" (28.6\%) which was related to topics in medical curriculum such as Fiqh Ibadah for the sick. Twenty-three point eight percent (23.8\%) of work were in the "Medical Treatment for Muslim Patients" which focuses on Ramadan and diabetes and joint problems and Solat. Minimal work (7.9\%) was done in the "Ruqyah and Tibb an-Nabawi in Contemporary Medicine" category (Figure 5).

\section{DISCUSSION}

The proposed classification of Islamization in Medicine

The work on Islamization in medicine performed in Kulliyyah of Medicine for the past 15 years were mainly in the areas of medical curriculum and research projects either by a researcher or group of researchers. Looking through the IREP database, we would be able to conclude that all the publications on Islamization in medicine fell in one of four common areas/themes, namely; 1) "Islamic Principles and Related Rulings in Medicine"; 2) "Medical Therapy for Muslim Patients"; 3) "Islamic Input in Medical Practice"; and 4) "Ruqyah and Tib an-Nabawi in Contemporary Medicine". Although these classifications were not set out at the beginning of the Islamization in medicine in 1994, we found that all researches and publications can be placed in one of these classifications.

Islamic Principles and Related Rulings in Medicine Islamic Principles and Related Rulings in Medicine deals with critical topics related to the higher purpose of Islamic Law or Maqasid Shariah. It also deals with Fiqh (understanding of the Islamic Law), prohibition and allowances (rukhsoh) in medicine and medical ethics. The theme also encompasses the wide definition of "Islamic Medicine" and the principles of Sunnah in medicine such as "prevention of the spread of contagious disease" or the principles of quarantine in contagious medical conditions. Based on the practices of earlier Muslims 


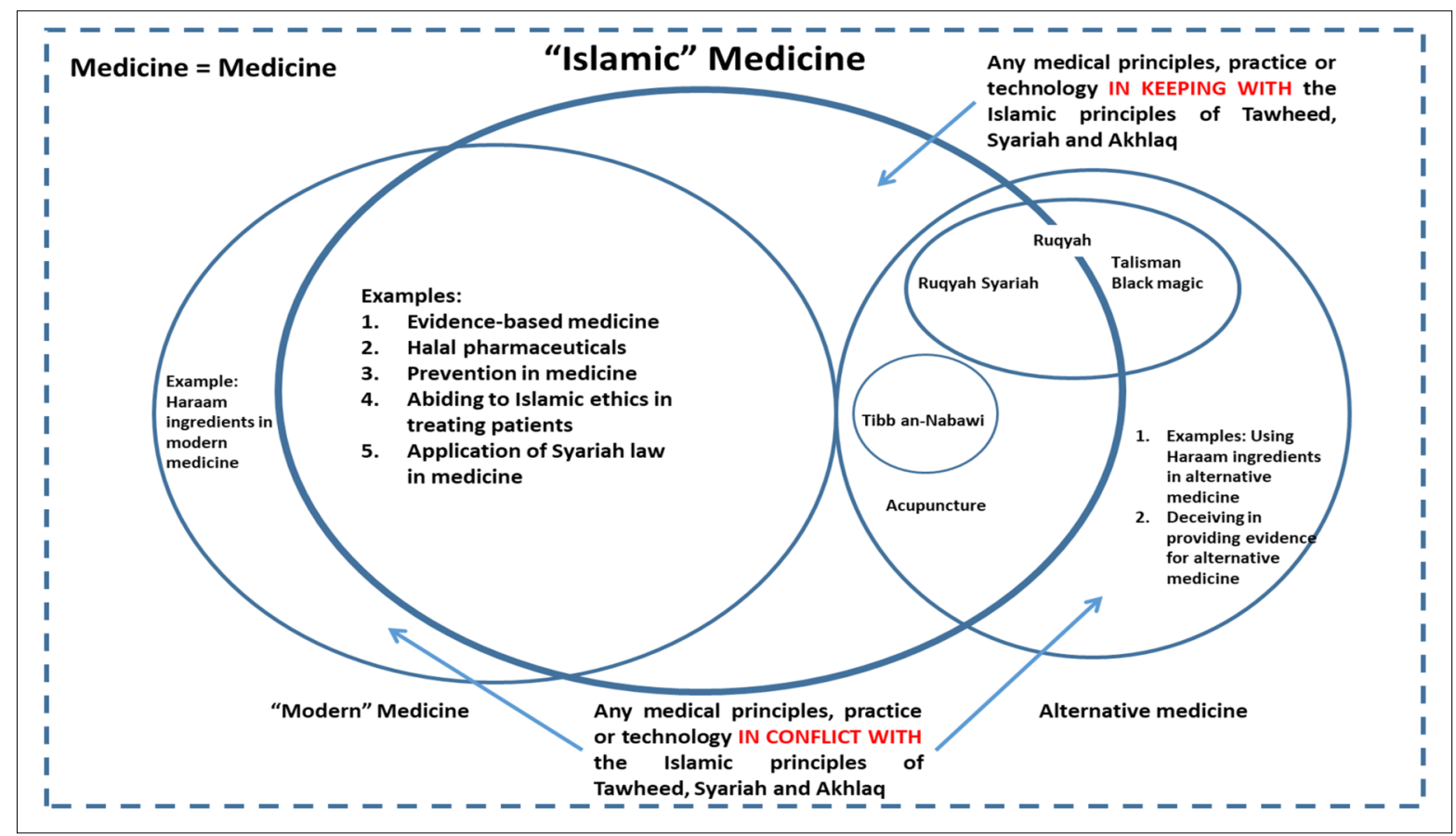

Figure 1: Medicine is medicine. "Islamic medicine" encompassed both modern or contemporary and alternative medicine. Note that any medical principles, practice or technology in keeping with the Islamic principles of Tawheed, Syariah and Akhlaq is Islamic. Any medical principles, practice or technology in conflict with these principles are non-Islamic be it modern or alternative medicine. Ruqyah is an Arabic term for "spell, charm, incantation". Tibb an-Nabawi forms a small portion of the vast scope of Islamic Medicine.

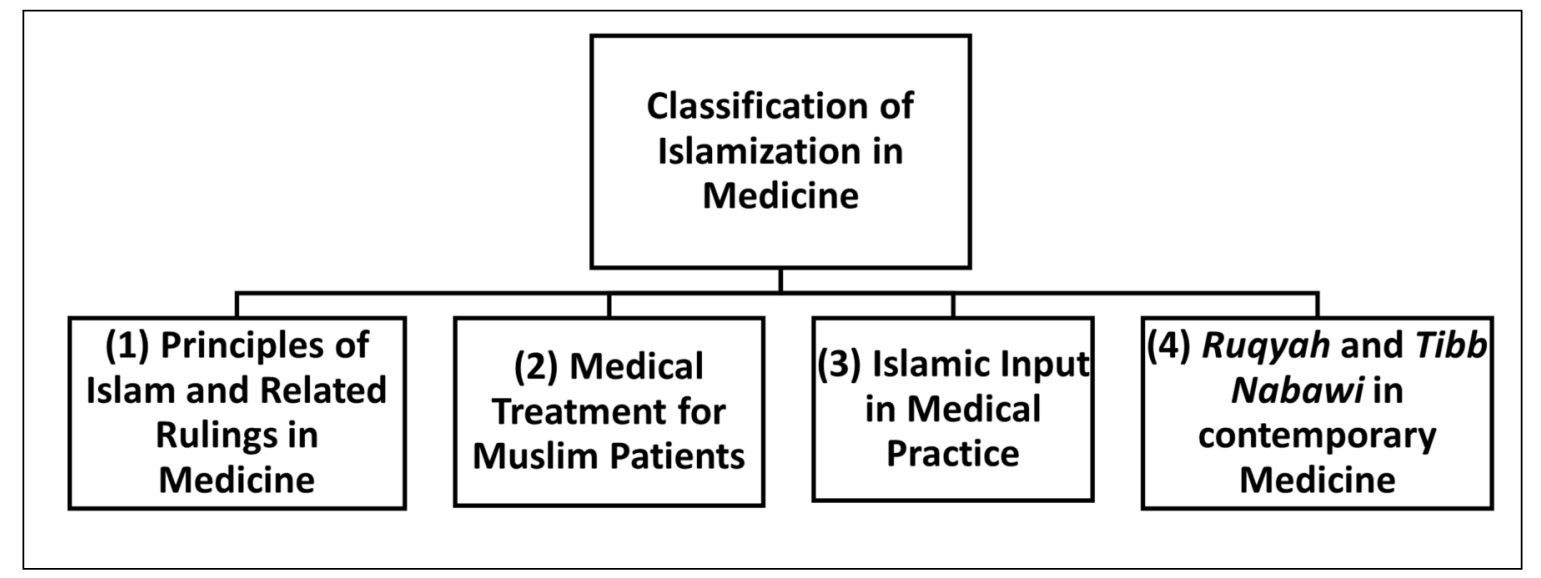

Figure 2: Proposed classification of Islamization in medicine based on common theme of researches and publications deposited in the IREP database.

scholars in medicine such as Ibn Sina, evidence based medicine is one of the important Islamic principle. In the 1st International Conference of International Medicine in Kuwait, 1987, Islamic medicine was defined as a medicine which is based on six basic characteristics; adhering to Islamic teachings and etiquette, adhering to logic in practicing medicine, holistic approach- paying equal attention to the body, mind and soul, universal approach-taking into account all resources, scientific approach-based on logical conclusions drawn from sound observations, accurate statistics and trustworthy experience and excellence. ${ }^{5}$ Examples of these type of publications are the work done by Prof Rathor et al, such as Attitudes toward euthanasia and related issues among physicians and patients in a multicultural society of Malaysia, Religion and spirituality in specific clinical situations in medical practice: a cross-sectional comparative study between patients and doctors in a tertiary care hospital in Malaysia, and The principle of autonomy as related to personal decision making concerning health and research from an 'Islamic Viewpoint'. ${ }^{-8}$

We find that majority of publications are classified under this theme is likely due to the early work on Islamic principles and medical ethics upon the opening of the Kulliyyah of Medicine. The prominent speaker in this topic at that particular time was Prof Dr Omar Hassan Kasule Sr, one of the pioneering lecturers following the establishment of Kulliyyah of Medicine, IIUM.

\section{Medical Treatment in Muslim Patients}

This theme of publications addresses the need of Muslims with particular disorders or medical condition. Emphasis is on the management of the disorders itself. Examples are Update on the management of diabetes during Ramadan fast for healthcare practitioners and The study on range of 


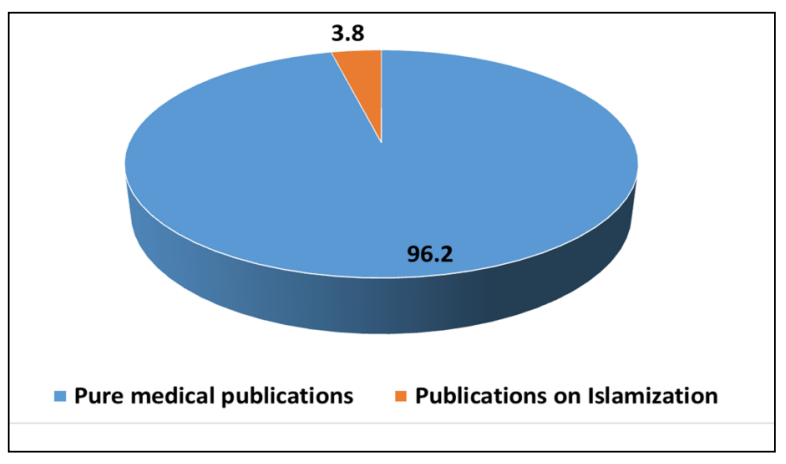

Figure 3: Percentage of publications on Islamization

motion of hip and knee in prayer by adult Muslim males. A preliminary report. ${ }^{9,10}$ To date, publications deposited in the IREP database related to this class are on Ramadan and diabetes, joint problems and Solat and management of depression, anxiety, gender identity disorder in Islamic point of view.

Publications under this theme are very much needed because the data for management of certain disorders for Muslims are scarce. Studying medical conditions in Muslims is important as Muslims are made obligatory to perform act of worship such as the formal prayers (Solat) and fasting in Ramadan. Certain medical conditions directly influence and affect the act of worship. In cases of osteoarthritis for an example, the movement in Solat will be restricted with conventional knee replacement prosthesis. Fasting in Ramadan for diabetics is another example of issues that need to be addressed. The American Diabetic Association published recommendation of management of diabetes in Ramadan, however the publication lacks Fiqh discussions and this posed a risk for misguidance for Muslims. ${ }^{11}$ Up to 2015 , there are only approximately 10 studies each related to insulin, sulphonureas and incretins use in Ramadan and only less than five are randomized controlled trials. Another example is studying the management of peptic ulcer disease for Muslims in Ramadan. Producing Halal pharmaceuticals should also be included under this class. These types of publications, if not the most crucial, can be considered a priority after Islamic Principles and Related Rulings in Medicine as it deals with real life Muslims problems which need fairly urgent solutions.

\section{Islamic Input in Medical Practice}

Islamic Input in Medical Practice deals mainly on routine Islamic rituals (Ibadah) affected by medical practices such as Figh Taharah and Solat (i.e rulings on purifications and prayers) for the disable

While the former classification discusses medical problems in Muslim patients, this category of publications discussed Islamic obligations in patients with specific medical conditions especially in matters pertaining to Ibadah and Muamalah (social transactions).

This is the second most developed publication area in Kulliyyah of Medicine. Examples of work by the Orthopedic team are Implementation of the Islamic input in Orthopaedics (IIIO) undergraduate medical curricula and practice: IIUM's experience, A short descriptive study on in-ward Muslim patients with diabetic foot disease practices in performing physical cleansing and prayer and How to perform religious duties in time of illness. A case study on a patient with head injury and upper limb trauma. ${ }^{12-}$ ${ }^{14}$ The Islamic Input in Orthopedics programme was established as early as 2008.

\section{Ruqyah and Tibb An-Nabawi in Contemporary Medical Practice}

This classification dwells in the subject of Prophetic Medicine either in the form of prayers (Dua), Ruqyah (an Arabic term for "spell, charm, incantation") and food or substances associated with cure as mentioned by the Prophet Muhammad (Peace be upon him). Black seed, dates and camel's urine are among examples of substances related to Medicine that the Prophet mentioned in his traditions. Islamic scholars differ in their opinion regarding Prophetic Medicine. A group of scholars from the Muhadetheen (example: Imam al-Bukhari) and Ibn Qayyim held the opinion that whatever the Prophet (Peace be upon him) said pertaining to

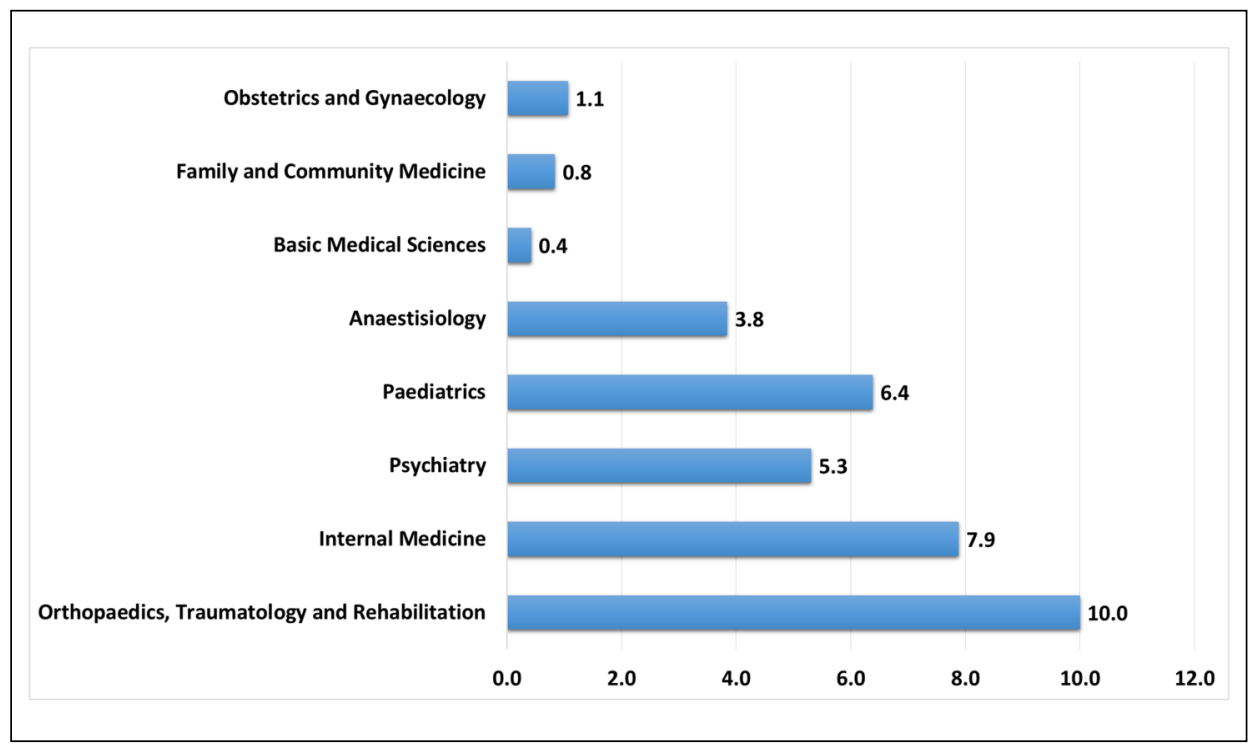

Figure 4: Percentage of publications on Islamization in medicine by departments in Kulliyyah of Medicine, IIUM. 


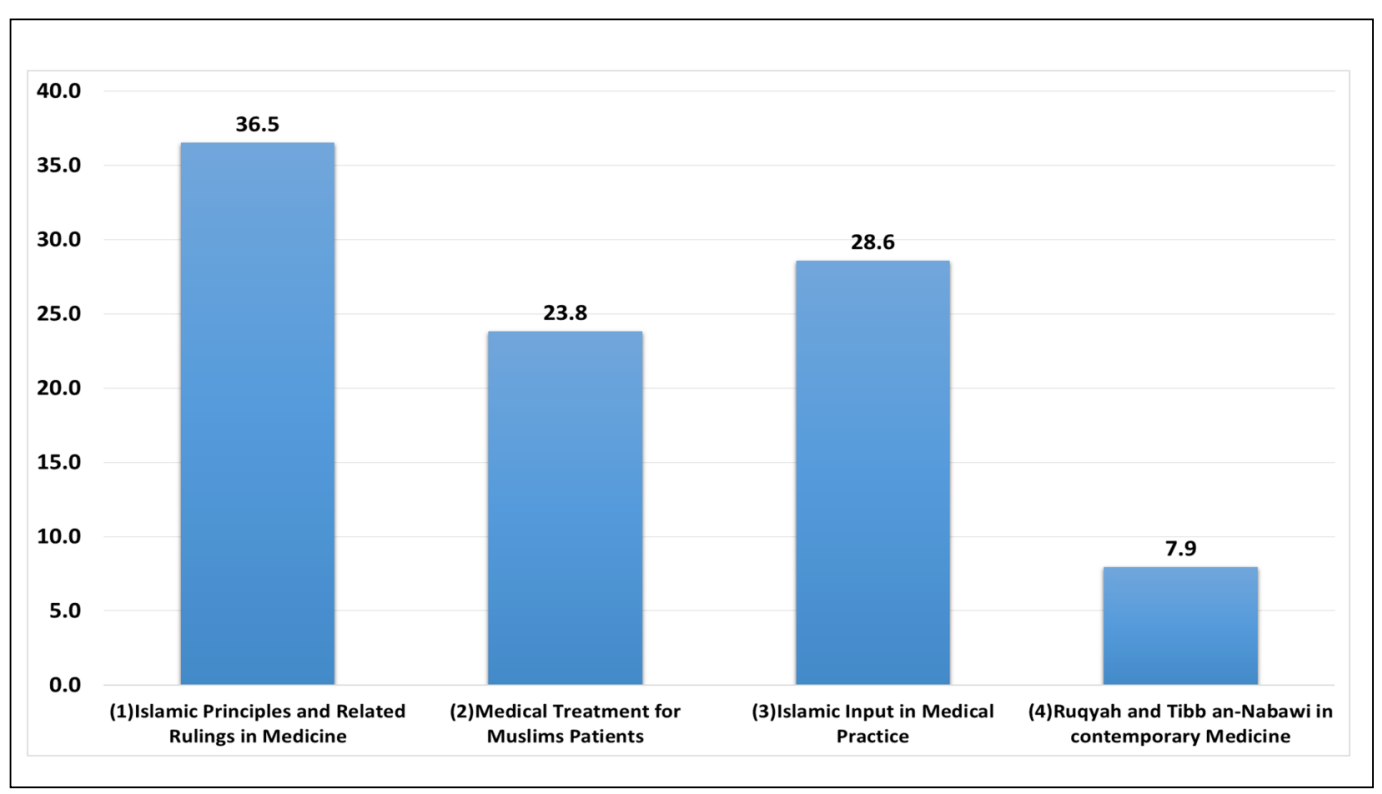

Figure 5: Percentage of publications of Islamization by the proposed classification system.

medicine are considered as revelations (Wahi), while scholars such as Al-Qadi lyyad, Ibn Khaldun and Muhammad Abu Zahrah held the opinion that whatever he mentioned were Arabic medicine and merely a custom that was widely accepted at the particular time (i.e. Jibiliyyah). ${ }^{15}$ Thus the latter opinion holds the fact that - except for Ruqyah or prayers-Prophetic Medicine is "eligible" for scientific testing. We are very much inclined to the latter opinion.

Examples of the work related to this classification include Pilot study on the effect of Yasiin recitation on the haemodynamics of ventilated patients and The effect of Qur'anic recitation on health: a brief review on previous clinical studies. ${ }^{16,17}$

It is noted that the publications in this area are very minimal. The possible reason is lack of fundamental expertise in the field of Quran and Sunnah (Prophet's Tradition) among the members of Kulliyyah of Medicine. The immediate strategy to overcome this weakness is through collaboration with Kulliyyah of Islamic Revealed Knowledge and Human Sciences (IRKHS) as this area of study would requires assistance from experts of Islamic Studies. In addition to that, an assistance from researcher of historical background may also be necessary to further guide the members of Kulliyyah of Medicine toward producing high quality review on the subject of Tibb an-Nabawi.

Input from academician/researcher in Islamic Studies on the correct and moderate position toward the practice of Ruqyah is mandatory. While acknowledging the merit of Ruqyah in Islamic Medicine is important, it is an uncalled act to abandon contemporary evidence based treatment and solely relies on Ruqyah following the diagnosis of common physical diseases such as liver cancers, epilepsy and ovarian tumors. Issue of performing scientific testing on Ruqyah needs careful consideration, as it involves Imaan or faith. Moreover, Ruqyah is the du'a or prayer. It is a form of 'ibadah- a spiritual rituals in order to bring ourselves nearer to God. Ruqyah syar'iyyah is du'a originated from the Quranic verses and authentic narrations of hadith. It can be argued that spiritual endeavours should not be subjected to scientific investigations and evidence, however it should heavily dependent to other form of evidences authentic divine proof. The empirical laboratory investigations on subtances or physical practice such as black seed, honey and hijamah or cupping is warranted at least to investigate the method to administer the medicine or practice.

Another theme which could be added to the classification is "History of Medicine and Islam" which focuses on the practice of medicine in the early days of Islam and the contribution of Islamic Scholars and Physician to the advancement of medicine. The importance of this theme is to remove the misconception that contemporary medicine emerges solely from the Western world. Acknowledging the contributions of Muslim scholars in medicine and realizing that their practice is evidence based would to some extent remove the dichotomy in medicine. Contribution of Muslims scholars in medicine continued after the Abassid age such as the least known fact there was tradition of merging the scientific knowledge and Islamic knowledge in madrasa all over the Ottoman empire during $1300-1600 .^{18}$

To the authors' knowledge, this was the first attempt at trying to classify the work on Islamization in Medicine among the members of Kulliyyah of Medicine. We hope that this proposed classification will further facilitate the Islamization effort in medicine to be more organized, inclusive of all aspect of medicine and relevant to current medical practice.

We anticipate the potential obstacles and barrier from accepting this classification due to the dichotomy of medicine among fellow researchers and health practitioners themselves. Majority were 
western trained. This can be overcome through continuous education and structured training on Islamization module. The most urgent need is to train the lecturers and the academician at least the basic tools of usul figh (basis of Islamic Law), mustolahul hadith (study on Prophetic Traditions), the basic form of tafseer (Quranic exegesis), Arabic and the exposure to various leading works by contemporary and classical scholars via the establishment of a diploma program in Islamic studies. On top of that, an advocacy role from the IIUM administrations in promoting the above effort is another critical element in ensuring its success.

\section{Limitation}

The reviewed publications were deposited under the Kulliyyah of Medicine. They may not reflect the actual number of publications related to Islamization in medicine done in IIUM. Other Kulliyyah and Centres such as Kulliyyah of Pharmacy, Allied Health Sciences, Laws, Education and Islamic Revealed Knowledge and Human Sciences were also involved in the Islamization in medicine. Publications on Islamization (written by IIUM authors) which are not deposited in IREP database are not captured in this analysis.

\section{CONCLUSION}

Low number of publications on Islamization was deposited in the IREP database for the past 15 years under the Kulliyyah of Medicine. Based on the proposed classification system, majority of publications were on "Islamic Principles and Related Rulings in Medicine" and "Islamic Input in Medical Practice". More work need to be done on "Medical Treatment for Muslim patients" and especially "Ruqyah and Tibb an-Nabawi in Contemporary Medicine".

\section{REFERENCES}

1. AL Issa I, ed. Al-Junun: Mental Illness in the Islamic World. International Universities Press, Inc; 2000.

2. Khan MS. Islamic Medicine. Routledge; 1986.

3. World Health Organisation. WHO vaccinepreventable diseases: monitoring system. 2016 global summary.

http://apps.who.int/immunization_monitoring/ globalsummary/incidences?c=MYS. Published 2016. Accessed September 22, 2016.

4. Abas A. Five diphtheria death in Malaysia so far. News Straits Times Online.

http://www.nst.com.my/news/2016/06/15559

$1 /$ five-diphtheria-deaths-malaysia-so-far. Published June 29, 2016. Accessed September 22, 2016.

5. Ahmad YA-H. The Islamic Guideline on Medicine. Darussalam; 2010.

6. Rathor MY, Ab rani MF, Shahar MA, Jamalludin AR, Che Abdullah ST, Omar AM. Attitudes toward euthanasia and related issues among physicians and patients in a multiqcultural society of Malaysia. J Fam Med Prim Care. 2014;3(3):230-237.

7. Rathor MY, Abdul Rani MF, Shah M, et al. The principle of autonomy as related to personal decision making concerning health and research from an "Islamic Viewpoint." J Islam Med Assoc North Am. 2011;43(1):27-34.

8. Rathor MY, Akter SFU, Abdul Rani MF, Mohd Shah AS. Religion and spirituality in specific clinical situations in medical practice: a crosssectional comparative study between patients and doctors in a tertiary care hospital in Malaysia. Med J Islam World Acad Sci. 2009;17(2):103-110.

9. Sharifudin MA, Arshad AA, Johari MH, et al. The study on range of motion of hip and knee in prayer by adult Muslim males. A preliminary report. Int Med J Malaysia. 2015;14(1):49-58.

10. Rathor MY, Fauzi AR, Omar AM. Update on the management of diabetes during Ramadan fast for healthcare practitioners. Int Med J Malaysia. 2014;13(2):67-72.

11. Al-Arouj M, Assad-Khalil S, Buse J, et al. Recommendations for management of Diabetes during Ramadhan. Diabetes Care. 2010;33(8):1895-1902.

12. Sharifudin MA, Che Ahmad A, Abdul Rahman $\mathrm{AF}$, et al. How to perform religious duties in time of illness. A case study on a patient with head injury and upper limb trauma. In: Seminar on Islamization of Medical Curriculum and Practice. Kuantan, Pahang; 2013.

13. Che Ahmad A, Sharifudin MA, Ayeop MAS, Mustafa NF, Alias N, Abdul Aziz NA. A short descriptive study on in-ward Muslim patients with diabetic foot disease practices in performing physical cleansing and prayer. In: International Conference on Islamic Medical Education (IC-ISME) 2015 in Conjunction with International Multi-Conference on Education \& Technology (IMCET) 2015. Nilai, Negeri Sembilan; 2015.

14. Sharifudin MA, Ayeop, Mohd Adham Syah Che Ahmad A. Implementation of the Islamic input in Orthopaedics (IIIO) undergraduate medical curricula and practice: IIUM's experience (2002-2014). In: Revelation \& Science in the 21st Century. ; 2015:141-148.

15. Zainul Abidin MA. Apakah itu perubatan Islam? MInda Tajdid.

http://drmaza.com/home/?p=1361. Published 2011. Accessed September 22, 2016.

16. Ariff M, Mai Ashikin N, Razali M, Johari B, Wan Azman W. Pilot study on the effect of Yasiin recitation on the haemodynamics of ventilated patients. Int Med J Malaysia. 2013;12(2):45-49.

17. Mai Ashikin N, Ariff M, Aminudin C. The effect of Qur'anic recitation on health: a brief review on previous clinical studies. In: Seminar on Islamization of Medical Curriculum and Practice. Kuantan, Pahang; 2013.

18. Ihsanoglu E. Transfer of Modern Science and Technology to the Muslim World, Advanced Islamic Studies (IAIS) Malaysia.; 2011. 